\title{
Immature Citrus Fruit Extracts Enhance the Apoptosis Inducing Potential of Cisplatin in Human Malignant Melanoma A375 Cells via Regulation of Nitric Oxide and Inhibitor of Apoptosis Family (IAP)
}

\author{
Ji Hye Kim and Min Young Kim* \\ Toxicology Laboratory, Faculty of Biotechnology, College of Applied Life Science, Jgiu National University, Jeju 690-756, Korea
}

Received January 29, 2014 /Revised March 25, 2014 /Accepted March 29, 2014

\begin{abstract}
In a previous study, we found that methanolic extracts of immature fruits of Satuma mandarin (Citrus unshiu Marc. var. okitsu) contained relatively high amounts of phytochemicals. Here we show that a combined treatment consisting of immature fruits of Satuma mandarin and cisplatin induced strong apoptotic response in human melanoma A375 cells. We further investigated the mechanisms by which immature fruits of Satuma mandarin augment cisplatin-induced apoptosis in A375 cells. Satuma mandarin up-regulated the expression of nitric oxide synthase (NOS), elevated nitric oxide (NO') production, and weakening the anti-apoptotic signals inhibitor of apoptosis (IAP) family, thus facilitating the process of apoptosis. These results suggest that immature fruits of Satuma mandarin in combination with cisplatin might have therapeutic value in melanoma treatment worthy of further development.
\end{abstract}

Key words : A375 cells, cisplatin, immature citrus fruits, inhibitor of apoptosis (IAP) family,nitric oxide

\section{서 론}

흑색종(melanoma)은 멜라닌 세포의 악성화로 발생하며 전 체 피부암의 $4 \%$ 를 차지하지만 그 사망률은 $80 \%$ 에 이르는 치 명적인 피부암이다[18, 30, 32]. 여타 암종과 비교하여 볼 때 흑색종은 내부 장기로 빠르게 전이되고 화학요법 및 방사선요 법에 높은 저항성을 가지기 때문에 조기 발견 후 외과적 수술 을 통한 절제만이 현재까지 유일한 치료법으로 인정받고 있다 $[10,35]$. 서양에서는 흑색종으로 인한 사망률이 높고 매년 발 병률이 지속적으로 증가하고 있어 관련연구가 활발히 진행되 고 있지만, 국내에서는 그 연구가 미미한 수준으로 이를 활성 화하기 위한 다양한 방안이 마련되어야 할 것으로 보인다[29, 33].

효과적인 암의 치료와 예방에 있어서 비정상적인 세포나 암세포의 apoptosis 유발은 많은 치료제의 표적이 되고 있으 며, apoptosis는 크게 세포막의 death receptor에 특정 ligand 가 결합함으로써 개시되는 extrinsic pathway와 mitochondrial dysfunction을 중심으로 한 intrinsic pathway로 구분할 수 있다. Intrinsic pathway는 nitric oxide $\left(\mathrm{NO}^{\circ}\right)$ 와 같은 reactive nitrogen species (RNS)의 자극에 의해 활성화될 수 있

\section{*Corresponding author}

Tel : +82-64-754-3349, Fax : +82-64-756-3351

E-mail : jeffmkim@jejunu.ac.kr

This is an Open-Access article distributed under the terms of the Creative Commons Attribution Non-Commercial License (http://creativecommons.org/licenses/by-nc/3.0) which permits unrestricted non-commercial use, distribution, and reproduction in any medium, provided the original work is properly cited.
으며, 일반적으로 과량 발생된 $\mathrm{NO}^{\circ}$ 가 superoxide anion $\left(\mathrm{O}_{2}{ }^{-}\right)$ 과 반응하여 peroxynitrite (ONOO)등 반응성이 큰 free radi$\mathrm{cal}$ 을 생성함으로써 주변 조직에 nitrosative stress를 야기하는 것으로 알려져 있다[13, 14].

암세포는 inhibitor of apoptosis (IAP)단백질이 caspase-3와 caspase-9와 결합하여 그 활성을 무력화함으로 apoptosis 발생 을 억제하는 것으로 보고되고 있으며, 현재까지 사람에서는 8개의 IAP family (NIAP, XIAP, cIAP-1, cIAP-2, survivin, apollen, livin, ILP-2)가 존재하는 것으로 알려져 있다. 이 중 survivin 유전자는 세포사멸뿐만 아니라 세포주기 중 G2/M 기의 진행을 저해하여 IAP 중 유일하게 세포분열에 관여하고 방광암, 위암, 직장암 등에서의 발현 감소는 세포사멸과 항암 제에 대한 감수성을 증가시키는 것으로 조사되어있다[27, 36, 37]. 또한 X-chromosome-linked IAP (XIAP)는 일반적으로 암 세포에서 높게 발현되고 여러 유발인자에 의한 발현의 감소는 전립선암, 흑색종의 증식 억제 및 apoptosis를 항진시키는 작 용을 하는 것으로 보고되었다[1, 31, 34].

한편 제주감귤산업은 재배 기술의 발달로 인한 과잉 생산을 방지하고 고품질의 감귤을 생산하기 위한 열매 솎기 작업으로 매년 약 5-10만 톤에 이르는 미성숙과 처리에 애로를 겪어왔 다. 게다가 2012년부터 런던협약에 따라 공해상에 부산물 투 기가 불가능해짐에 따라 이에 대한 대책이 매우 시급한 실정 이므로 감귤 미성숙과의 적절한 처리법이 요구되고 있다. 기 존 연구 결과에 따르면 항산화, 항알레르기, 항염증, 암 증식 억제 작용 등에 유효한 효과를 보이는 다양한 생리활성 성분 함량이 감귤 성숙과에 비해 미성숙과에서 월등히 높은 것으로 나타나[7], 감귤 미성숙과의 활용방안에 대한 연구가 지역감귤 
산업 활성화 및 농가 소득 증진에 기여할 수 있을 것으로 전망 된다.

그러므로 본 연구에서는 cisplatin과 감귤 미성숙과를 병용 처리하여 인간 흑색종 $\mathrm{A} 375$ 세포에 대한 항암작용을 증강시 킬 수 있는지 조사함으로써 감귤 미성숙과의 효율적인 자원화 방안을 마련하고 기존 합성 항암제의 독성 및 부작용을 최소 화시키는 안전하고 효과적인 흑색종 치료법을 마련하고자 한다.

\section{재료 및 방법}

\section{시료준비}

본 연구에 사용된 흥진조생 미성숙과는 제주특별자치도 농 업기술원으로부터 제공받아 24시간 동안 동결건조 후 분쇄하 였다. 건조된 감귤 미성숙과에 $5 \mathrm{~g} / 100 \mathrm{ml}$ 의 농도가 되도록 $100 \%$ methanol을 첨가하여 $25^{\circ} \mathrm{C}, 150 \mathrm{rpm}$ 으로 72 시간 동안 교반하며 유효성분을 추출하였다. 추출액을 $1500 \mathrm{rpm}$ 에서 15 분 간 원심분리 시키고 $0.45 \mu \mathrm{m}$ 의 여과 필터로 걸러내어 부유 성분을 제거하였으며, 감압 농축을 통하여 얻어낸 고형성분 $(1.13 \mathrm{~g})$ 을 다시 동결 건조시켜 보관하였다. 실험 시에는 dimethyl sulfoxide (Amresco, Solon, Ohio, USA)를 이용하여 $200 \mathrm{mg} / \mathrm{ml}$ 의 농도로 stock solution을 만든 다음 적정 농도로 배지에 희석하여 사용하였다.

\section{실험재료}

실험에 사용된 cisplatin은 Calbiochem (Salt Lake City, UT, USA)에서 구입하였으며, 세포배양에 필요한 시약들은 Lonza (Walkersville, MD, US)에서 구입하였다. 세포생존율 측정을 위해 사용된 cell proliferation kit (MTT)는 Roche (Indianapolis, $\mathrm{IN}, \mathrm{USA})$ 에서, DNA fragmentation 확인을 위한 genelute ${ }^{\mathrm{TM}}$ mammalian genomic DNA miniprep kit와 total RNA 분리를 위한 TRI reagent는 Sigma (St. Louis, MO, USA), TOP script $^{\mathrm{TM}}$ one-step RT PCR kit는 Enzynomics (Daejeon, Korea) 에서 각각 구입하여 사용하였다.

\section{세포배양}

본 실험에 사용된 인간 흑색종 A375 세포는 Massachusetts Institute of Technology (MIT)의 G. N. Wogan 박사로부터 분주 받아 10\% heat-inactivated fetal bovine serum (FBS), 100 units $/ \mathrm{ml}$ penicillin, $100 \mathrm{\mu g} / \mathrm{ml}$ streptomycin과 L-glutamine 을 첨가한 dulbecco's modified eagle medium (DMEM) 배지 를 이용하여 $37^{\circ} \mathrm{C}$ 습윤한 $\mathrm{CO}_{2}$ incubator $\left(5 \% \mathrm{CO}_{2} / 95 \%\right.$ air)에 서 배양하였다. 세포가 배양용기의 $80 \%$ 정도 증식하였을 때 적정수의 세포를 유지하기 위하여 phosphate-buffered saline (PBS, pH 7.4)으로 세척한 후 $0.25 \%$ trypsin-EDTA를 처리하여 계대 배양하였고 배양액은 3-4일마다 교환하였다.

\section{세포생존율 측정}

세포 생존율 측정은 Liber 등[24]의 방법을 변형하여 조사 하였으며, 6 well plate에 세포를 $2 \times 10^{6}$ cells/well이 되도록 분주하고 감귤 미성숙과를 농도별, 시간별로 처리한 후 세포 배양액과 $0.4 \%$ trypan blue를 동량으로 넣어 hematocytometer를 이용하여 세포의 증식 정도를 광학현미경으로 관 찰하였다. Cisplatin의 세포독성은 MTT assay를 이용하여 측 정하였으며, 96 well plate에 $5 \times 10^{4}$ cells/well이 되도록 세포 를 분주하고 cisplatin을 농도별로 48시간 동안 처리한 후 packard EL340 microplate reader (Bio-Tek Instruments, Winooski, VT, US)로 $550 \mathrm{~nm}$ 에서의 흡광도를 측정하였다. 측정은 모두 세 번 이루어졌으며, 시험물질을 첨가하지 않은 대조군 세포수를 $100 \%$ 로 하여 각 시험물질의 상대적인 생존 율을 구하였다.

\section{Cell cycle 분석}

Cell cycle은 Li 등[26]의 방법에 따라 분석하였다. 시험 세포 주 $\left(2 \times 10^{6}\right.$ cells $/$ well $)$ 에 감귤 미성숙과와 cisplatin을 48 시간 동 안 처리한 후 세포를 회수하여 $\mathrm{PBS}$ 로 세척하고 $70 \%$ 에탄올로 $4{ }^{\circ} \mathrm{C}$ 에서 30 분 동안 고정하였다. 고정된 세포는 $1200 \mathrm{rpm}$ 으로 12 분 동안 원심분리한 다음 상층액을 제거하고 $1 \% \mathrm{FBS}$ 가 포 함된 PBS로 2-3회 세척하였다. 준비된 세포를 $500 \mu \mathrm{gg} / \mathrm{ml}$ 의 propidium iodide (Sigma)로 염색한 후 $10 \mu \mathrm{g} / \mathrm{\mu l}$ 의 RNase (Amresco)가 포함된 $\mathrm{PBS}(1 \% \mathrm{FBS})$ 에 넣어 $37^{\circ} \mathrm{C}$ 에서 30 분 간 반응시키고 BD FACS calibur $^{\mathrm{TM}}$ flow cytometer (BD biosciences, San Jose, CA, US)를 이용하여 세포주기를 분석하 였다.

\section{DNA fragmentation 분석}

세포 $\left(2 \times 10^{6}\right.$ cells/well $)$ 에 감귤 미성숙과와 cisplatin 처리하 여 48 시간 동안 배양하고, 세포를 수집하여 genelute ${ }^{\mathrm{TM}} \mathrm{mam}-$ malian genomic DNA miniprep kit로 DNA를 분리하였다. 분리한 DNA는 $1.8 \%$ agarose gel에서 $60-120$ 분 $(50 \mathrm{~V})$ 동안 전 기영동하여 ethidium bromide (EtBr, Sigma)로 염색하고 UV transilluminator 하에서 DNA 단편화 현상을 관찰하였다.

\section{Reverse transcription-polymerase chain (RT-PCR) 에 의한 $\mathrm{mRNA}$ 발현 분석}

위와 동일한 조건으로 배양된 세포를 모은 다음 TRI reagent를 처리하여 total RNA를 분리하였으며, 분리된 RNA 는 UV spectrophotometer (Ultrospec 2100 pro, GE healthcare, US)로 정량 한 후 TOP script ${ }^{\mathrm{TM}}$ one-step RT PCR kit와 각각의 primer (Table 1), DEPC water를 넣고 유전자증폭기 (Genepro, Bioer Tech, Hangzhou, China)에서 증폭하였다. mRNA 발현 수준을 비교하기 위하여 각 PCR 산물을 ethidium bromide 용액이 첨가된 $1.5 \%$ agarose gel에서 60-90분 
Table 1. Sequence of primers used for RT-PCR

\begin{tabular}{|c|c|c|}
\hline Gene name & & Sequence \\
\hline \multirow{2}{*}{ Neuronal NOS } & Sense & 5'-TTGGGGGCCTGGGATTTCTGG-3' \\
\hline & Antisense & 5'-GTTGGCATGGGGGAGTGAGC-3' \\
\hline \multirow{2}{*}{ Inducible NOS } & Sense & 5'-CCAGTGACACAGGATGACCTTCAG-3' \\
\hline & Antisense & 5'-TGCCATTGTTGGTGG AGTAACG-3' \\
\hline \multirow{2}{*}{ Endothelial NOS } & Sense & 5'-CCAGCTAGCCAAAGTCACCAT-3' \\
\hline & Antisense & 5'-GTCTCGGAGCCATACAGGATT-3' \\
\hline \multirow{2}{*}{ X-chromosome-linked IAP } & Sense & $5^{\prime}$-ACACCATATACCCGAGGAAC- $3^{\prime}$ \\
\hline & Antisense & 5'-CTTGCATACTGTCTTTCTGAGC-3' \\
\hline \multirow{2}{*}{ Survivin } & Sense & 5'-GCATGGGTGCCCCGACGTTG-3' \\
\hline & Antisense & 5'-GCTCCGGCCAGAGGCCTCAA-3' \\
\hline \multirow{2}{*}{$\beta$-actin } & Sense & 5'-GGTCATCTTCTCGCGGTTGGCCTTGGGGT-3' \\
\hline & Antisense & 5'-CCCCAGGCACCAGGGCGTGAT-3' \\
\hline
\end{tabular}

$(50 \mathrm{~V})$ 동안 전기영동하였으며, $\beta$-actin을 internal control로 사용하였다.

\section{Nitrite 생성량 측정}

Nitrite 생성량은 Green 등[11]의 방법을 변형하여, 감귤 미 성숙과 및 cisplatin을 농도별로 48시간 동안 처리한 배양용기 에서 $100 \mu \mathrm{l}$ 씩의 배양액을 취하여 동량의 Griess reagent (Sigma)를 첨가하고 이를 10 분간 실온에 반응시켜 oxidation product인 $\mathrm{NO}_{2}^{-}$생성정도를 $540 \mathrm{~nm}$ 파장에서 측정하였으며, 이때 $\mathrm{NO}_{2}^{-}$농도에 대한 표준곡선은 $\mathrm{NaNO}_{2}$ 를 사용하여 작성 하였다.

\section{통계 처리}

본 실험의 결과는 평균 \pm 표준편차로 표시하였으며, 통계 처리는 student's $t$-test에 의해 $p \propto 0.05$ 인 경우 유의한 것으로 판정하였다.

\section{결과 및 고찰}

\section{감귤 미성숙과에 의한 $\mathrm{A} 375$ 세포의 증식 억제}

감귤 미성숙과 추출물이 $\mathrm{A} 375$ 세포의 증식에 미치는 영향
과 그 유효농도를 설정하기 위하여 trypan blue exclusion assay를 이용하여 세포 생존율 변화를 측정하였다. 감귤 미성숙 과를 농도별 $(0-200 \mu \mathrm{g} / \mathrm{ml})$ 로 24-72시간 동안 처리한 결과 Fig. $1 \mathrm{~A}$ 와 같이 농도 및 시간 의존적으로 $\mathrm{A} 375$ 세포의 생존율이 감소하였으며, 72 시간이 경과하였을 때 현저히 감소하여 약 $20 \%$ 의 생존율을 나타냈다. Jayaprakasha 등[17]에 따르면 감 귤류의 limonexic acid 및 $\beta$-sitosterol glucoside 성분이 대장 암 HT-29 세포의 증식 억제 작용을 하고, Yoo 등[38]은 감귤류 에 함유된 생리활성 물질이 전립선 암 DU145와 LN-Cap에 대해 암세포의 성장을 저해한다고 보고하고 있다. 또한, 감귤 의 flavonoid 유도체인 noblietin, hesperetin, naringenin 등이 여러 암종을 억제하는 것으로 밝혀지고 있어[2, 22, 28], 본 연 구에서도 감귤 미성숙과 추출물에 포함된 다양한 생리활성 물질 및 항산화 활성이 $\mathrm{A} 375$ 세포의 증식 억제 작용에 영향을 미친 것으로 생각된다(Fig. 1A).

\section{감귤 미성숙과와 cisplatin 병용 처리에 의한 apoptosis} 유발

Fig. 2A에 나타난 바와 같이 감귤 미성숙과 처리 시 apoptosis가 일어난 집단에 속하는 sub-G1기의 세포 빈도는 농도-의 존적으로 증가하여 $200 \mu \mathrm{g} / \mathrm{ml}$ 에서 약 $13 \%$ 를 보였는데, 대장
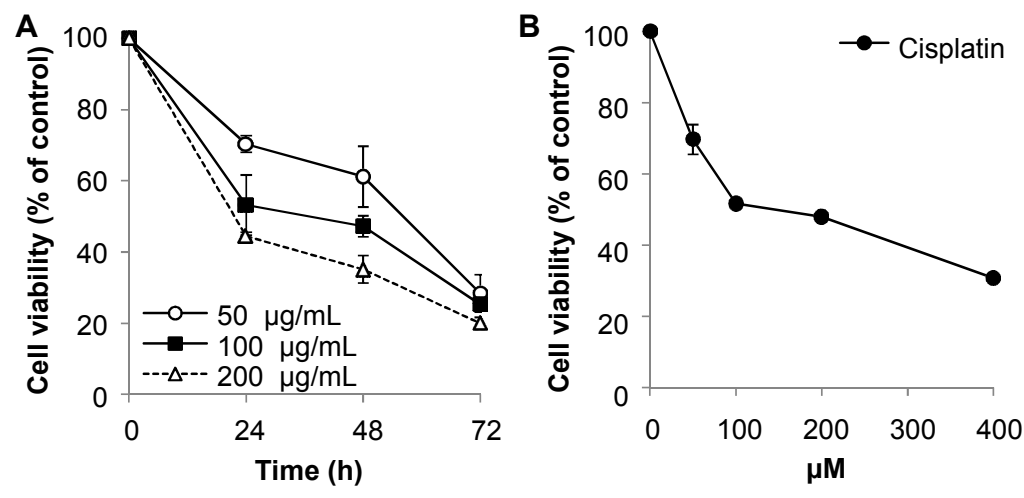

Fig. 1. Growth inhibition of human malignant melanoma A375 cells after treatment with immature citrus fruit (A) and cisplatin (B). The cells were treated with variable concentrations of immature citrus fruit for 24-72 hr or cisplatin for $48 \mathrm{hr}$. Each point is the mean \pm SD of three experiments. 
A

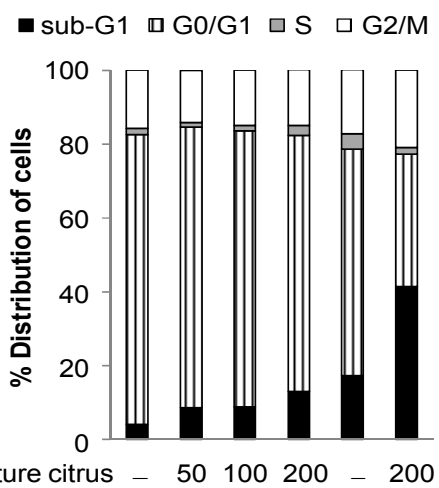

Immature citrus - $50100200-200$ $100 \mu \mathrm{M}$ Cisplatin

B

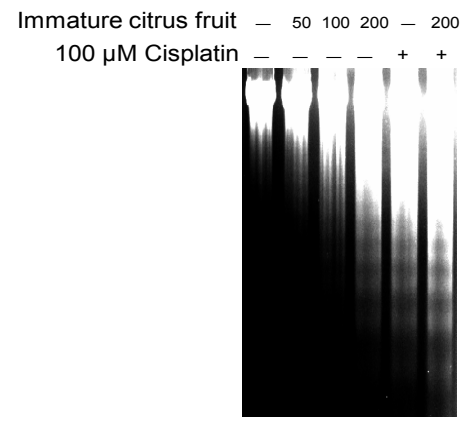

Fig. 2. Effect of immature citrus fruit on cisplatin-induced apoptosis in A375 cells. (A) Cells were treated with immature citrus fruit $(\mu \mathrm{g} / \mathrm{ml})$ and/or cisplatin for $48 \mathrm{hr}$, stained with PI, and analyzed for cell cycle using flow cytometry. (B) Internucleosomal DNA fragmentation induced in A375 cells by immature citrus fruit and/or cisplatin. Results are expressed as mean \pm SD from three separated experiments.

암 세포주와 백혈병 세포주에서도 감귤 추출물이 sub-G1 증가 에 따른 세포사멸을 유도하는 것으로 알려져 있다[19, 20].

Cisplatin은 유방암, 전립선암, 폐암 등 여러 암의 치료제로 이용되고 있는데 $[8,9,15]$, 이 중 흑색종 세포주에 대한 항암효 과는 SK mel-28 에서 Fas 활성화에 따른 apoptosis를 유발하거 나 $\mathrm{MeWo}$ 세포에서 caspase 활성 및 cytochrome $\mathrm{c}$ 방출을 유 도하여 사멸 효과를 나타내고 reactive oxygen species (ROS) 를 생성하여 M14 세포를 저해하는 등 다수 보고되어있다 [4, $6,12]$. 본 연구에서도 cisplatin 처리 시 흑색종 A375 세포의 증식이 농도 의존적으로 증가하였으며(Fig. $1 \mathrm{~B})$, 감귤 미성숙 과와 병용 시 약 $42 \%$ 의 sub-G1 arrest가 나타나 cisplatin 단독 처리군 $(17 \%)$ 에 비하여 뚜렷한 세포사멸 효과를 확인할 수 있 었다(Fig. 2A). 이 결과는 자궁경부암 세포주에서 cisplatin과 산삼배양근 추출물(또는 berberin)의 복합투여가 ROS 생성을 통한 항암 작용을 강화하며, cisplatin (또는 doxorubicin)과 녹차 추출물의 병용 처리가 폐암 세포주의 증식을 억제한다는 기존 연구결과와 유사한 경향을 나타내었다[21, 23].

Apoptosis 유도의 직접적인 증거가 되는 DNA fragmenta- tion 현상은 caspase가 활성화됨에 따라 $180-200 \mathrm{bp}$ 의 길이로 DNA가 분해되는 특성으로 인해 발생하는데, Fig. 2B와 같이 감귤 미성숙과에 의해 DNA laddering이 점차 증가하는 것을 확인할 수 있었으며 cisplatin 병용 처리 시 가장 뚜렷하게 관 찰됨을 알 수 있었다. 결론적으로 감귤 미성숙과에 의해 유도 된 A375 세포의 증식 억제는 apoptosis와 밀접한 연관성이 있으며, cisplatin과의 병용 처리를 통해 항암작용을 증강시킴 을 알 수 있었다.

\section{감귤 미성숙과와 cisplatin 병용 처리에 의한 NOS 발현} 및 nitrite 생성

$\mathrm{NO}^{\bullet}$ 는 3 가지 nitric oxide synthase (NOS): neuronal NOS (nNOS), inducible NOS (iNOS), endothelial NOS (eNOS)에 의해 L-arginine으로부터 생성되는 물질로 발생량에 따라 apoptosis를 항진시키거나 억제하는 역할을 하는 것으로 알려 져 있다 $[5,25]$. 이에 감귤 미성숙과 및 cisplatin에 의해 유도된

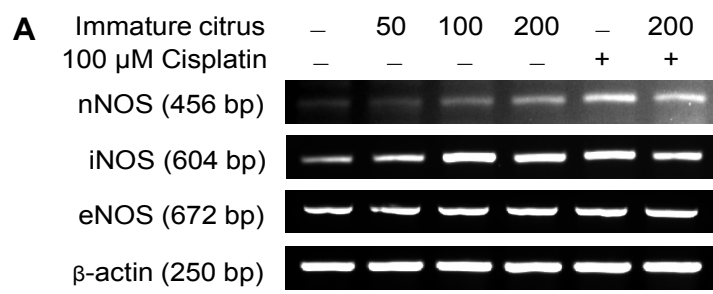

B
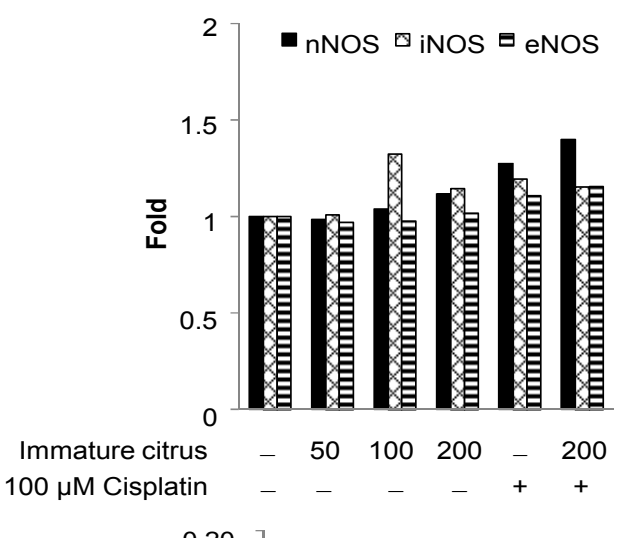

C

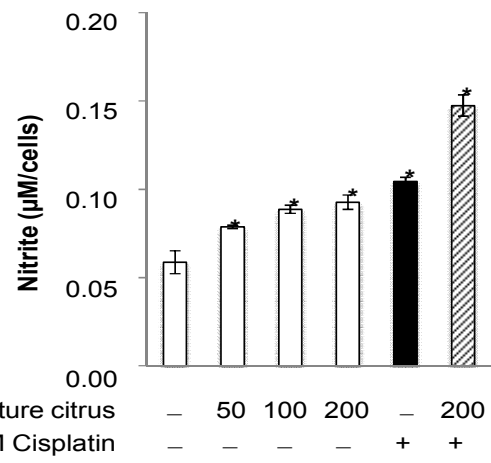

Fig. 3. Effect of immature citrus $(\mu \mathrm{g} / \mathrm{ml})$ and/or cisplatin on the expression of NOS isoforms (A and B) and nitrite production in A375 cells (C). The results are shown as the mean $\pm \mathrm{SD}$. ${ }^{*}, p<0.05$ compared with control. 


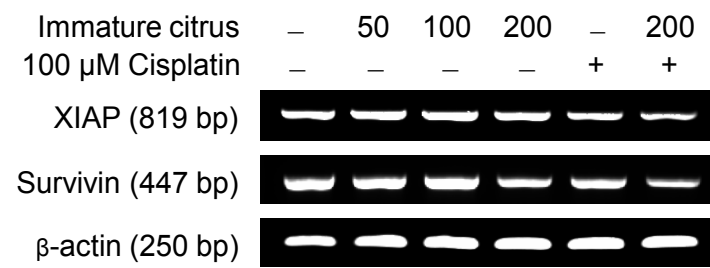

Fig. 4. Effect of immature citrus fruit and/or cisplatin on IAPs expression. Cells were treated with indicated concentration and analyzed by RT-PCR for levels of IAPs.

apoptosis와 $\mathrm{NO}^{\bullet}$ 와의 관련성을 파악하기 위하여 NOS의 발 현을 확인한 결과 3 가지 NOS 모두 전사 수준에서 발현이 증가 하였으며(Fig. 3A, Fig. 3B), nitrite 발생량 역시 NOS 발현과 유사한 경향을 나타내며 유의적으로 증가하였다. 특히 cisplatin과 병용 처리한 경우에는 nitrite 발생량이 cisplatin 단독 처리에 비해 1.5 배 증가하는 것을 확인할 수 있는데(Fig. 3C), 이는 천연물 추출물에 의해 유도된 $\mathrm{NO}^{\bullet}$ 생성이 암의 증식 억제 및 apoptosis를 유발한다는 많은 연구결과와도 부합된다 $[3,16]$. 따라서 감귤 미성숙과 및 cisplatin의 처리에 따른 A375 세포의 apoptosis 기전에 NOS를 활성화에 의한 nitrite 생성이 관여하는 것이라 유추된다.

\section{영향}

IAP family 발현에 미치는 감귤 미성숙과와 cisplatin의

감귤 미성숙과 및 cisplatin에 의해 유도된 자연사멸 기전 분석을 위하여 IAP family의 발현 양상을 mRNA 수준에서 탐색한 결과, 감귤 미성숙과 단독 처리 시 큰 변화를 관찰할 수 없었지만 cisplatin 단독 처리 시 survivin 및 XIAP의 발현 량이 감소하였으며 병용 처리한 경우 그 활성이 현저하게 저 해되었다(Fig. 4). 상기 IAP family의 발현 변화로 미루어보아 감귤 미성숙과와 cisplatin 병용 처리에 의한 apoptosis 증강 작용에 survivin 및 XIAP 발현의 감소가 연관되어 있음을 알 수 있다.

이상의 결과를 종합하여 보면 감귤 미성숙과가 cisplatin에 의해 유도된 인간 흑색종 A375세포의 apoptosis를 증강시키 는 효과를 지니고 있으며, NOS 발현에 따른 NO'생성과 IAP family 중 survivin 및 XIAP 발현 감소가 동반되어 있음을 알 수 있다. Cisplatin의 항암 효과를 감귤 미성숙과가 증대시킬 수 있기 때문에 보다 효율적인 항암치료가 가능할 것으로 기 대되며, 이러한 효과를 입증하기 위한 지속적인 연구가 필요 할 것이라 사료된다.

\section{감사의 글}

이 논문은 2014년도 제주대학교 학술진흥연구비 지원사업 에 의하여 연구되었습니다.

\section{References}

1. Ardecky, R. J., Welsh, K., Finlay, D., Lee, P. S., Lopez, M. G., Ganji, S. R., Ravanan, P., Mace, P. D., Riedl, S. J., Vuori, K., Reed, J. C. and cosford, N. D. P. 2013. Design, synthesis and evaluation of inhibitor of apoptosis protein (IAP) antagonists that are highly selective for the BIR2 domain of XIAP. Bioorg Med Chem Lett 23, 4253-4257.

2. Arul, D. and Subramanian, P. 2013. Naringenin (citrus flavonone) induces growth inhibition, cell cycle arrest and apoptosis in human hepatocellular carcinoma cells. Pathol Oncol Res 19, 763-770.

3. Aquilano, K., Filomeni, G., Di Renzo, L., Vito, M. D., Stefano, C. D., Salimei, P. S., Ciriolo, M. R. and Marfe, G. 2007. Reactive oxygen and nitrogen species are involved in sorbitol-induced apoptosis of human erithroleukaemia cells K562. Free Radic Res 41, 452-460.

4. Biroccio, A., Benassi, B., Amodei, S., Gabellini, C., Bufalo, D. D. and Zupi, G. 2001. C-Myc down-regulation increase susceptibility to cisplatin through reactive oxygen species-mediated apoptosis in M14 human melanoma cells. Mol Pharmacol 60, 174-182.

5. Brune, B., Knethen, A. V. and Sandau, K. B. 1999. Nitric oxide (NO) : an effector of apoptosis. Cell Death Differ 6, 969-975.

6. Choi, S. L. and Myung, P. K. 2004. Induction of apoptosis by cisplatin, heptaplatin and sunpla in human melanoma (SK-MEL-28) cell line. Yakhak Hoeji 48, 147-152.

7. Choi, S. Y., Ko, H. C., Ko, S. Y., Hwang, J. H., Park, J. G., Kang, S. H., Han, S. H., Yun, S. H. and Kim, S. J. 2007. Correlation between flavonoid content and the no production inhibitory activity of peel extracts from various citrus fruits. Biol Pharm Bull 30, 772-778.

8. Comella, P., Abate, G., Di Finizio, G., Daponte, A. and Zarrilli, D. 1990. Treatmen of resistant non-hodgkin's lymphomas with cisplatin, etoposide, and bleomycin. Cancer Chemother Pharmacol 26, 306-309.

9. Cown, P. 2001. The Platium agents: a role in breast cancer treatment? Semin Oncol 28, 28-37.

10. Garbe, C., Hauschild, A., Volkenandt, M., Schadendorf, D., Stolz, W., Reinhold, U., Kortmann, R. D., Kettelhack, C., Frerich, B., Keilholz, U., Dummer, R., Sebastian, G., Tilgen, W., Schuler, G., Mackensen, A. and Kaufmann, R. 2007. Evidence and interdisciplinary consense-based german guidelines: diagnosis and surveillance of melanoma. Melanoma Res 17, 393-399.

11. Green, L. C., Wagner, D. A., Glogowski, J., Skipper, P. L., Wishnok, J. S. and Tannenbaum, S. R. 1982. Analysis of nitrate, nitrite, and $[15 \mathrm{~N}]$ nitrate in biological fluids. Anal Biochem 126, 131-138.

12. Helmbach, H., Kern, M. A., Rossmann, E., Renz, K., Kissel, C., Gschwendt, B. and Schadendorf, D. 2002. Drug resistance towards etoposide and cisplatin in human melanoma cells is associated with drug-dependent apoptosis deficiency. J Invest Dermatol 118, 923-932.

13. Hirst, D. G. and Robson, T. 2007. Nitrosative stress in cancer 
therapy. Front Biosci 12, 3406-3418.

14. Hirst, D. G. and Robson, T. 2010. Nitrosative stress as a mediator of apoptosis: implications for cancer therapy. Curr Pharm Des 16, 45-55.

15. Hogberg, T., Glimelius, B. and Nygren, P. 2001. A systematic overview of chemotherapy effects in ovarian cancer. Acta Oncol 40, 340-360.

16. Hsieh, B. S., Huang, L. W., Su, S. J., Cheng, H. L., Hu, Y. C., Hung, T. C. and Chang, K. L. 2011. Combined arginine and ascorbic acid treatment induces apoptosis in the hepatoma cell line HA22T/VGH and changes in redox status involving the pentose phosphate pathway and reactive oxygen and nitrogen species. J Nutr Biochem 22, 234-241.

17. Jayaoraksha, G. K., Jadegoud, G. A., Gowda, N. and Patil, B. S. 2010. Bioactive compounds from sour orange inhibit colon cancer cell proliferation and induce cell cycle arrest. $J$ Agric Food Chem 58, 180-186.

18. Jemal, A., Siegel, R., Ward, E., Xu, J., Smigal, C. and Thun, M. J. 2006. Cancer statistics. CA Cancer J Clin 56, 106-130.

19. Kang, S. A., Park, H. J., Kim, M. H., Lee, S. Y., Han, S. W. and Leem, K. H. 2005. Citri reticulatae viride pericarpium extract induced apoptosis in SNU-C4, human colon cancer cells. I Ethnopharnacol 97, 231-235.

20. Kim, G. H., Lee, M. H., Han, M. H., Park, C., Hong, S. H. and Choi, Y. H. 2013. Induction of apoptosis by citri pericarpium methanol extract through reactive oxygen species generation in U937 human leukemia cells. J Life Sci 23, 1057-1063.

21. Lee, B. R., Park, J. Y. and Park, P. S. 2011. Effect of green tea extract on cisplatin- or doxorubicin-induced cytotoxicity in human lung cancer cell lines. J Korean Soc Food Sci Nutr 40, 619-624.

22. Lee, C. J., Wilson, L., Jordan, M. A., Nguyen, V., Tang, J. and Smiyun, G. 2010. Hesperidin suppressed proliferations of both human breast cancer and androgen-dependent prostate cancer cells. Phutother Res 24, 15-19.

23. Lee, M. Y. 2010. Cisplatin and extract of tissue cultured mountain ginseng-induced apoptosis in human cervical cancer cells. Korean J Microscopy 40, 133-138.

24. Liber, H. L. and Thilly, W. G. 1982. Mutation assay at the thymidine kinase locus in diploid human lymphoblasts. Mutat Res 94, 467-485.

25. Liu, L. and Stamler. J. S. 1999. NO: an inhibitor of cell death. Cell Death Differ 6, 937-942.

26. Li, Q. U., Pang, B., Kiziltepe, T., Trudel, L. J., Engelward, B. P., Dedon, P. C. and Wogan, G. N. 2006. Threshold effects of nitric oxide-induced toxicity and cellular responses in wild-type and p53-null human lymphoblastoid cells. Chem Res Toxicol 19, 399-406.

27. Lu, F., Altieri, D. C. and Tanigawa, N. 1998. Expression of a novel antiapoptosis gene, survivin, correlated with tumor cell apoptosis and p53 accumulation in gastric carcinomas. Cancer Res 58, 1808-1812.

28. Luo, G., Guan, X. and Zhou, L. 2008. Apoptosis effect of citrus fruit extract nobiletin on lung cancer cell line A549 in vitro and in vivo. Cancer Biol Ther 7, 966-973.

29. Meier, F., Satyamoorthy, K., Nesbit, M., Hsu, M. Y., Schittek, B., Garbe, C. and Herlyn, M. 1998. Molecular events in melanoma development and progression. Front Biosci 3, 1005-1010.

30. Megahed, M., Schon, M., Selimovic, D. and Schon, M. P. 2002. Peliability of diagnosis of melanoma in situ. Lancet 359, 1921-1922.

31. Passante, E., Wurstle, M. L., Hellwig, C. T., Leverkus, M. and Rehm, M. 2013. Systems analysis of apoptosis protein expression allows the case-specific prediction of cell death responsiveness of melanoma cells. Cell Death Differ 20, 1521-1531.

32. Rezaul, K., Wilson, L. L. and Han, D. K. 2008. Direct tissue proteomics in human diseases: potential applications to melanoma research. Expert Rev Proteomics 5, 405-412.

33. Saida, T. 2001. Recent advance in melanoma research. $J$ Dermatol Sci 26, 1-13.

34. Saleem, M., Qadir, M. I., Perveen, N., Ahmad, B., Saleem, U., Irshad, T. and Ahmad, B. 2013. Inhibitors of apoptotic proteins: new targets for anticancer therapy. Chem Biol Drug $82,243-251$.

35. Satyanoorthy, K., Bogenrieder, T. and Herlyn, M. 2001. No longer a molecular black box-new clues to apoptosis and drug resistance in melanoma. Trends Mol Med 7, 191-194.

36. Swana, H. S., Grossman, D., Anthony, J. N., Weiss, R. M. and Altieri, D. C. 1999. Tumor content of the antiapoptosis molecule survivin and recurrence of bladder cancer. $N$ Engl J Med 341, 452-453.

37. Yamamoto, T., Manome, Y., Nakamura, M. and Tanigawa, N. 2002. Down-regulation of survivin expression by induction of the effector cell protease receptor- 1 reduces tumor growth potential and results in an increased sensitivity to anticancer agents in human colon cancer. Eur J Cancer 38, 2316-2324.

38. Yoo, K. M. and Hwang, I. K. 2004. In vitro effect of yuza (citrus junos SIEB ex TANAKA) extracts on proliferation of human prostate cancer cells and antioxidant activity. Korean J Food Sci 36, 339-344. 


\section{초록 : 산화질소와 IAP 조절을 통한 감귤 미성숙과의 cisplatin-유발 흑색종 A375 세포의 자연사멸 증강 효과}

\section{김지혜 · 김민영*}

(제주대학교 생명공학부 독성학 실험실)

선행연구에서 감귤 미성숙과 메탄올 추출물이 다량의 생리활성 물질을 함유하고 있다는 것을 보고한 이래, 본 연구에서 감귤 미성숙과를 cisplatin과 병용 시 인간 흑색종 A375 세포를 대상으로 강력한 자연사멸능을 유도함을 확인할 수 있었다. 또한 감귤 미성숙과가 cisplatin에 의한 자연사멸능 증가에 관한 메커니즘을 조사한 결과, 산화 질소 합성효소(NOS)의 활성증가로 인한 산화질소 발생량 증가와 더불어 항자연사멸 신호인자인 IAP의 발현을 감소시킴으로 인간 흑색종 세포의 자연사멸을 촉진시키는 것으로 나타났다. 이상의 결과는 감귤 미성숙과와 cisplatin의 병용 요법이 흑색종 치료 효율을 높일 수 있을 것으로 기대되며 이러한 효과를 입증하기 위한 지속적인 연구가 필요할 것이라 사료된다. 